\title{
Perception Of Stress and IIIness Among Nurses in Psychiatry
}

1 Tomislav Bočkor

1 Josipa Kurtović

1 Ana Pavelić Tremac

1 Neuropsychiatric Hospital "dr. Ivan Barbot", Popovača, Croatia

Article received: 09.02.2021.

Article accepted: 12.04 .2021$.

Author for correspondence:

Tomislav Bočkor

Neuropsychiatric Hospital "dr. Ivan Barbot"

Jelengradska 1, Popovača, Croatia

E-mail: bockort@gmail.com

https://doi.org/10.24141/2/5/1/5

Keywords: allostasis, allostatic load, disease, homeostasis, nurses, stress

\section{Abstract}

Homeostasis is important for maintaining balance and normal functioning of the organism. Allostatic mechanisms further help to establish this balance. If the body is under stress for a longer period, a complex condition in the body called allostatic load occurs. If such a load lasts longer, the risk of developing diseases increases significantly. This study was conducted anonymously with the aim of determining the health status of male and female nurses in the Neuropsychiatric hospital "Dr. Ivan Barbot" in Popovača and their exposure to everyday stressors in the workplace. The main purpose was to examine the relationship between stress and the health status of nurses in relation to gender, age, and seniority. A total of 142 nurses participated. The Health Questionnaire and Workplace Stress Questionnaire were used. The results showed that the most common diseases nurses suffer from are cardiovascular diseases, thyroid diseases, gastrointestinal diseases, and allergies. Women showed higher sensitivity to stress than men. The most common stressors faced by nurses in the workplace are inadequate personal income, inadequate workspace and material resources for work, lack of staff, daily contingencies, 24-hour responsibility, and administrative work. This study found an association between age and, consequently, work experience with the likelihood of illness, although both the healthy and the sick perceive equal levels of stress. One disadvantage of this study is that it covers a large area and deals with general issues, but it can certainly be a starting point for further research. Many questions remain open, which means there is a need for further research and study of the link between stress and illness. 


\section{Introduction}

Nursing is a stressful, high-risk occupation. Stress affects not only health and personal and work satisfaction, but also the facilities in which nurses work. Their absence from work and their replacement can both have an impact on patient care (1). Workplace stressors depend on the individual, and everyone reacts to them differently. Some factors that can cause stress in the workplace can be task planning, a person's role in an organization, career development, work relationships, organization, life-work balance, workplace conditions, etc. Most of the respondents gained their work experience by doing shift work. Shift work, especially at night, can increase the risk of developing chronic diseases, depending on the number of years spent doing shift work (2). Night work increases the risk of cancer (most often breast cancer), metabolic syndrome and heart disease (3). Nurses who work night shifts are at three times higher risk of obesity, and the risk increases with years of service or night work (4). Higher levels of stress increase the risk of disease (5). According to a study conducted at a psychiatric ward, $50 \%$ of nurses developed symptoms of anxiety (6). Depression and stress were present in about $40 \%$ of respondents. Women have proven to be a more vulnerable group, and as the number of years of service increases, so does the number of people suffering from anxiety and depression. Warning signs that may indicate excessive stress are most often dizziness, jaw tension, tooth friction, general pain, headaches, indigestion, sleep problems, increased or decreased appetite, muscle tension, fatigue, exhaustion, sweaty palms, trembling, tremor, weight gain or weight loss, sexual problems, etc. Secondary traumatic stress (STS) occurs when working with people who have experienced a particular trauma. It is also called compassion exhaustion. In psychiatry, it is most associated with working with people suffering from PTSD. STS affects the behaviour and emotions of workers who have knowledge of other people's traumatic experiences. The symptoms can be emotional, cognitive, physical, and behavioural.

\section{Homeostasis}

After the concept and mechanism of homeostasis was identified, decades later there were still many discussions on the subject. Later in the 20th century some scientists believed that the body does not merely act when something happens, but that it also has the ability to predict certain situations. Homeostasis implies the state of an internal balance of the organism. Usually, negative influences are those that require adaptation from the organism. There are also positive factors that require certain changes in the body, such as pregnancy. Such changes also require easier adjustment because the body perceives them as a more natural and less harmful phenomenon. Homeostatic control mechanisms use predefined values (starting points). Some examples include the body temperature, fluid volume, gastric acid $\mathrm{pH}$, electrolyte values, etc. Since 1911, various theories have been developed about the connection between pathological conditions and stress. It has been shown that emotional stimuli can cause physical damage to the body. Hanse Seyle believed that every organism has an adaptive energy that is limiting. This would mean that the body can cope with stress, but prolonged stress can lead to burnout, which can result in a reduced ability to adapt to diseases (7).

\section{Allostasis}

Allostasis is a process that supports homeostasis (8). Homeostasis achieves adaptation based on previously mentioned starting points, while allostasis achieves adaptation through changes. Homeostasis is important for life while allostasis is important for the balance achieved through changes in the environment and living conditions. The allostatic process begins with the activation of the autonomic nervous system (ANS). The ANS sends impulses to the hypothalamus, which releases corticotropin. Corticotropin affects the release of adrenocorticotropin (ACTH) in the pituitary gland, which then enters the bloodstream. ACTH stimulates the production and release of adrenaline and cortisol. Adrenaline and cortisol stimulate the release of glucose stores into the bloodstream, which is needed for the body to overcome a given situation or escape from it. When the danger passes, all these intermediaries return to their original state (7). Cortisol and cytokines cause inflammatory changes in the body. Inflammatory changes require an immune response, and a negative response of the organism suppresses the immune response in order to protect the organism. By suppressing the immune system, the body becomes vulnerable to pathogens. The short-term effect of neu- 
rotransmitters and hormones is desirable, but during sustained stress their effect becomes detrimental.

\section{Allostatic condition}

In the allostatic state, the balance of primary mediators changes. The length of the allostatic state depends on food intake or stored energy that feeds homeostatic mechanisms (8). The final result of a chronic allostatic condition is allostatic load or overload.

\section{Allostatic load and overload}

Allostatic load occurs when allostatic mechanisms are active when they should not be (7). Continuous excessive release of stress hormones leads to 3 types of overload (7): excessive exposure to stress hormones due to normal stress; inability to suppress the allostatic mechanism when it is not needed or inability to adapt to the same stressor; and inability to stimulate the allostatic response when this is needed, which activates other harmful mechanisms.

Type 1 overload implies conditions in which the energy needs of the organism exceed the actual energy intake. In that case, the body's energy reserves are activated. Such a condition can result in weight loss.

Type 2 overload occurs when energy needs are not sufficient, so the body tries to create as much stock or even more than needed. This can result in food intake (fatty foods), metabolically unbalanced changes, and the accumulation of fat deposits around the waist.

\section{Diseases associated with allostatic overload}

It is believed that the modern way of life and poor socio-economic conditions pose a great risk for developing various diseases. Cardiovascular diseases are the most common diseases associated with adverse socioeconomic conditions. Studies have shown that hypertension occurs to workers whose jobs are unstable (8), while those who are exhausted have a significantly increased risk of developing cardiovascular disease (8). Abdominal obesity is also associated with stress, which leads to an increased risk of developing type 2 diabetes and cardiovascular disease (8). Tension is considered a risk factor for infections, especially when experiencing disturbances in interpersonal relationships and negative life situations (8). It has been shown that there is a connection between socioeconomic conditions and the development of mental disorders such as depression, schizophrenia, and substance abuse (8).

\section{The role of the brain, hormones, and neurotransmitters in stress and disease}

It is still not clear why some people fall ill under the influence of chronic stress of similar intensity and type, while others do not. The reason for this may be that the perception of stress in the brain of each individual is different and that each organism displays different behaviour and physiological response to stress. By storing previous events in the brain, the body can predict the necessary physiological response in advance. It is believed that these previously stored stressful events affect the vulnerability of the organism (9). Impaired brain function can consequently affect the body's ability to cope and self-regulate (9). Thyroid hormones play an important role in protecting the body from disease. They are important for the antioxidant process which reduces oxidative stress in the body. As the main "energy" gland, the thyroid plays a significant role in the body's energy supply. Neurotransmitters are important for communication within brain areas that respond to stress (prefrontal cortices, amygdala, hypothalamus, etc.). Within these areas, cortisol cooperates with neurons and astrocytes and produces strong effects on the functional and anatomical changes of the brain's structure. Insulin, some peptides, oestrogen, etc., can also take part in these changes.

\section{Aim}

The goal was to investigate and determine the health status of male and female nurses and their exposure to daily stressors in the workplace in order to examine the relationship between stress and health status of respondents in relation to gender, age, and years of work experience.

\section{Methods}

The survey was conducted anonymously, using a questionnaire with a total of 31 questions, three of which 


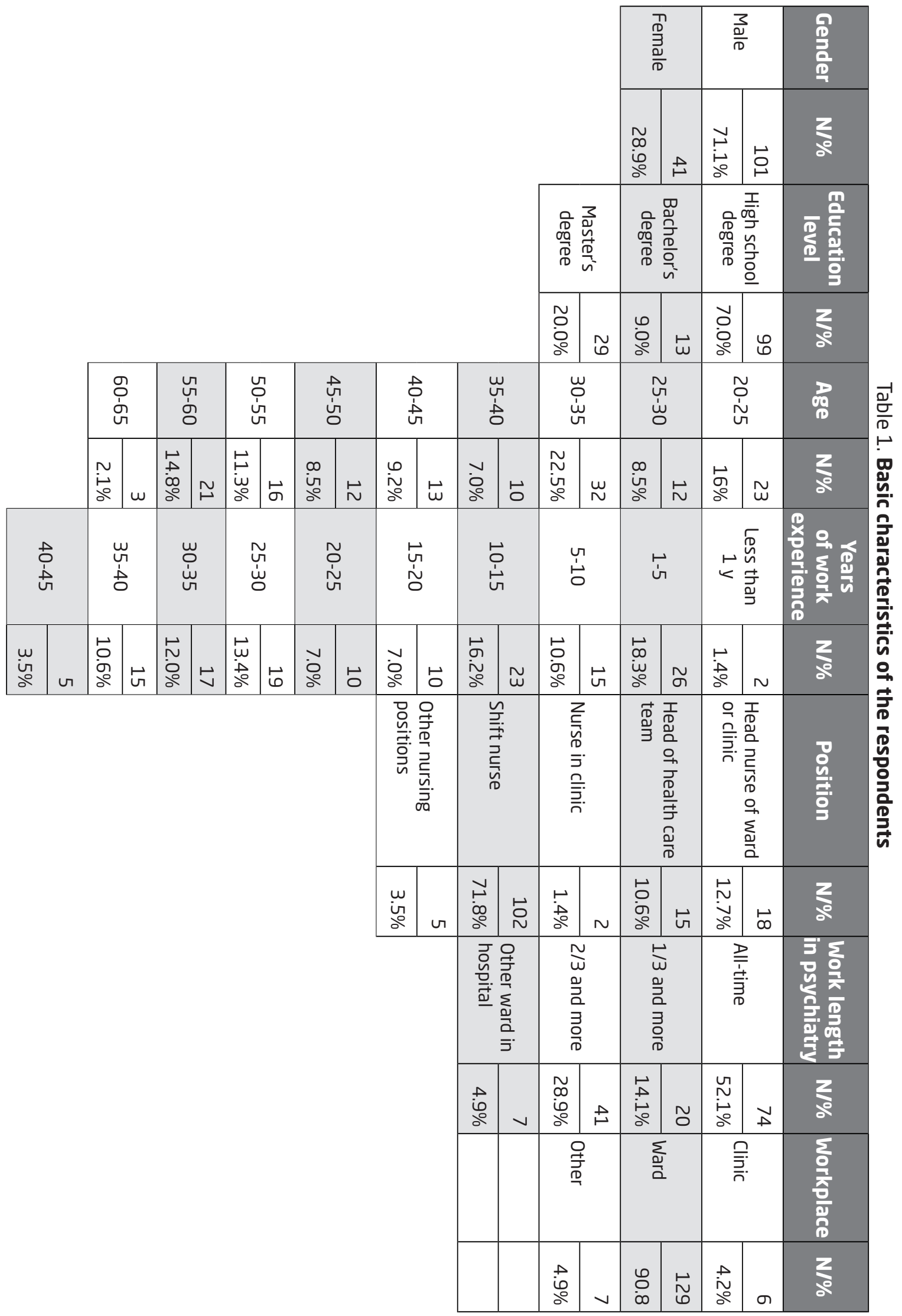


are related to demographic data (gender, age, and education), four to information regarding employment and years of work experience, while other questions are part of the Health Questionnaire (by FDI World Dentist Federation) and the Workplace Stress Questionnaire (by "Andrija Štampar" School of Public Health). The Health Questionnaire had to be adapted to the respondents and modified for that purpose. The Workplace Stress questionnaire contains 17 items where respondents choose one of the following answers: 1 (not stressful at all), 2 (rarely stressful), 3 (sometimes stressful), 4 (stressful), or 5 (extremely stressful). The range of results for each respondent is from 17 to 85 . The average result of perceived stress in the workplace is obtained by dividing the total gross result by the number of items.

142 respondents, exclusively employees of the Neuropsychiatric Hospital "Dr. Ivan Barbot" completed the survey. For the purposes of the study, the online service Google Forms (https://docs.google.com/ forms/d/17C6y0jg0cVF_gSSjh19zkNWbt-sC-WYRPrvsYoXxXtE/edit) was used, and the respondents were contacted via the Viber application, which was used to send the link to the form. All responses (completed questionnaires) were received between 3 and 9 March 2020. The respondents answered the questions by choosing the answer that most accurately described their opinions. All necessary analyses were performed in Microsoft Excel and the SPSS program. Participation in the study was voluntary and anonymous and was approved by the hospital ethics committee.

\section{Results}

The questionnaire was completed by a total of 142 respondents, of whom $71 \%$ were male, had secondary education (70\%) and were mostly between the ages of 30 and 35. Most of the respondents work in shifts and have worked in psychiatric wards throughout their careers. Table 2. shows the respondents' answers to the items of

Table 2. Health Questionnaire ( $\mathbf{N}=\mathbf{1 4 2})$

\begin{tabular}{|c|c|c|}
\cline { 2 - 3 } \multicolumn{1}{c|}{} & Yes & No \\
\hline \multirow{2}{*}{ Do you suffer from any diseases? } & 58 & 84 \\
\cline { 2 - 3 } $\begin{array}{c}\text { Have you been treated by a medical doctor in } \\
\text { the last two years? }\end{array}$ & $40.8 \%$ & $59.2 \%$ \\
\cline { 2 - 3 } $\begin{array}{c}\text { last two years? } \\
\text { Have you been treated in a hospital in the }\end{array}$ & $67.6 \%$ & 46 \\
\cline { 2 - 3 } & 24 & 32.4 \\
\hline \multirow{2}{*}{ Have you ever been treated with radiation? } & $16.9 \%$ & $83.1 \%$ \\
\hline \multirow{2}{*}{ Have you ever received chemotherapy? } & 0 & 142 \\
\cline { 2 - 3 } & $0 \%$ & $100 \%$ \\
\hline Have you ever had any infectious & 1 & 141 \\
\cline { 2 - 3 } (contagious) diseases? & $0.7 \%$ & $99.3 \%$ \\
\hline \multirow{2}{*}{ Have you ever received a blood transfusion? } & 38 & 104 \\
\cline { 2 - 3 } & $26.8 \%$ & $73.2 \%$ \\
\hline \multirow{2}{*}{ Have you ever had a stabbing incident? } & 10 & 132 \\
\cline { 2 - 3 } & $7 \%$ & $93 \%$ \\
\hline Have you ever been tested for infectious & 32 & 110 \\
\cline { 2 - 3 } diseases? & $22.5 \%$ & $77.5 \%$ \\
\hline \multirow{2}{*}{ Have you had fertility problems? } & 44 & 98 \\
\cline { 2 - 3 } & $31 \%$ & $69 \%$ \\
\hline
\end{tabular}


the Health Questionnaire. 60\% of those surveyed at the time of the study were not suffering from any diseases, but almost 70\% have been to a family doctor for some reason in the last two years. Most were not hospitalized during the same period, and none were treated with radiation, while only one employee received chemotherapy. $30 \%$ of them regularly take some form of therapy, $40 \%$ only occasionally, and $32 \%$ never take any form of therapy. 70 to $80 \%$ of those surveyed had a stab incident at the workplace and were tested for infectious diseases. Only $7 \%$ of the respondents had some fertility problems and the respondents were most often (30\%) pregnant twice, while $16 \%$ were pregnant three or more times and $8.5 \%$ once. Most of them did not have any problems or complications with pregnancy (72.5\%). Approximately $22 \%$ of them had complications during pregnancy, 4\% after, and only one respondent had complications before pregnancy itself.

The most common diseases among those respondents who were between 20 and 35 years of age and had up to 10 years of work experience are allergic diseases, asthma, and thyroid disease. In the age group of 30 to 40 and between 10 and 20 years of work experience, the most common diseases are anaemia, high blood pressure, sinusitis, and thyroid disease. High blood pressure, thyroid disease, allergic difficulties, gastrointestinal diseases, and sinusitis are the most common diseases of the age group between 45 and 60 and between 30 and 40 years of work experience.

One respondent aged between 50 and 55, a shift nurse in a department who spent between 30 and 35 years of work experience in psychiatry, listed a number of illnesses she had suffered from during her life or is currently suffering from (anaemia, sinusitis, thyroid disease, arthritis, autoimmune disease, gastroesophageal reflux, gastroduodenal ulcer, neurological diseases, glaucoma, dermatological diseases).

In the Health Questionnaire, the most common diseases mentioned by the respondents were sinusitis, allergic difficulties, thyroid diseases, and high blood pressure.

$41 \%(\mathrm{~N}=58)$ of the respondents stated that they were currently suffering from a disease and $59 \%$ $(\mathrm{N}=84)$ stated that they were not ill. $36 \%(\mathrm{~N}=51)$ stated that they did not suffer from any of the diseases they could choose from. $42 \%(\mathrm{~N}=38)$ indicated one of the diseases they could choose from, while
Table 3. Respondents' current or past diseases and conditions

\begin{tabular}{|c|c|}
\hline DISEASE/CONDITION & $\mathbf{N}$ \\
\hline Atherosclerosis & 1 \\
\hline Glaucoma & 1 \\
\hline Pacemaker & 1 \\
\hline Prostate problems & 1 \\
\hline Constant cough & 1 \\
\hline Stent implantation & 1 \\
\hline Oral candidiasis & 1 \\
\hline Hepatitis & 2 \\
\hline TB & 2 \\
\hline Thrombosis & 2 \\
\hline Enlarged glands & 3 \\
\hline Coronary heart disease & 4 \\
\hline Mental problems & 6 \\
\hline Neurological diseases & 7 \\
\hline Diabetes & 8 \\
\hline Asthma & 9 \\
\hline Arthritis & 9 \\
\hline Autoimmune disease & 10 \\
\hline Dermatological diseases & 11 \\
\hline Gastroduodenal ulcer & 11 \\
\hline Anaemia & 13 \\
\hline Gastroesophageal reflux & 16 \\
\hline Sinusitis & 20 \\
\hline Thyroid disease & 22 \\
\hline Allergic difficulties & 23 \\
\hline High blood pressure & 27 \\
\hline TOTAL: & 212* \\
\hline None of the above & 51 \\
\hline
\end{tabular}

*Total number of diseases of the respondents 
Table 4. Diseases that afflict respondents by gender

\begin{tabular}{|c|c|c|c|}
\hline \multicolumn{2}{|c|}{ Female } & \multicolumn{2}{|c|}{ Male } \\
\hline Disease & $\mathbf{N}$ & Disease & $\mathbf{N}$ \\
\hline Thyroid disease & 17 & Hypertension & 7 \\
\hline Allergic difficulties & 16 & Diabetes & 4 \\
\hline Sinusitis & 15 & Sinusitis & 4 \\
\hline Hypertension & 15 & Asthma & 3 \\
\hline Gastroesophageal reflux & 14 & Allergic difficulties & 3 \\
\hline Anaemia & 10 & Gastroduodenal ulcer & 3 \\
\hline Dermatological diseases & 10 & Gastroesophageal reflux & 2 \\
\hline Autoimmune disease & 8 & Autoimmune disease & 2 \\
\hline Arthritis & 9 & Neurological diseases & 2 \\
\hline Gastroduodenal ulcer & 7 & Mental problems & 2 \\
\hline Neurological diseases & 5 & Prostate problems & 1 \\
\hline Coronary heart disease & 5 & Constant cough & 1 \\
\hline Asthma & 4 & TB & 1 \\
\hline Diabetes & 3 & Thyroid disease & 1 \\
\hline Thrombosis & 2 & & \\
\hline Enlarged glands & 2 & & \\
\hline Hepatitis & 1 & & \\
\hline Candidiasis & 1 & & \\
\hline
\end{tabular}

$58 \%(\mathrm{~N}=53)$ indicated that they currently suffer or have suffered from more than one disease.

Most of the respondents $95.8 \%(\mathrm{~N}=136)$ have not suffered from a disease, nor do they now suffer from any of the malignant diseases they could choose from. Six subjects reported suffering from cervical cancer, testicular cancer, and melanoma.

The most common disease that occurs among male respondents is hypertension, while among female respondents there are several diseases, such as thyroid disease, allergic difficulties, sinusitis, hypertension, and gastroesophageal reflux.
More than half of the respondents (57.7\%) believe that the work they do has an impact on their previous and/or current health status.

Table 5 shows the statements of the questionnaire "Stress in the workplace of hospital health workers" and the percentage of agreement of respondents with each statement. A substantive analysis of the claims suggests that respondents experience the following factors as the most prominent causes of stress: inadequate personal income, inadequate workspace and material resources for work, lack of staff, unforeseen everyday situations, and 24-hour responsibility. Numerous administrative tasks are al- 
Table 5. Overview of all statements from the questionnaire "Stress in the workplace of hospital health workers" and percentages with regard to the different degree of agreement with each statement

\begin{tabular}{|l|l|l|l|l|l|}
\hline \multirow{2}{*}{ Stressors } & \multicolumn{5}{|c|}{ PERCENTAGE OF AGREMENT } \\
\cline { 2 - 6 } & \multicolumn{1}{|c|}{$\mathbf{1}$} & \multicolumn{1}{|c|}{$\mathbf{2}$} & \multicolumn{1}{|c|}{$\mathbf{3}$} & \multicolumn{1}{|c|}{$\mathbf{5}$} \\
\hline 1. Inadequate personal income. & 3.5 & 19.7 & 45.1 & $\mathbf{2 6 . 1}$ & $\mathbf{5 . 6}$ \\
\hline $\begin{array}{l}\text { 2. Inadequate material resources for appropriate work (fi- } \\
\text { nancial restrictions) }\end{array}$ & 3.5 & 17.6 & 49.3 & $\mathbf{2 3 . 2}$ & $\mathbf{6 . 3}$ \\
\hline 3. Inadequate workspace. & 6.3 & 16.2 & 50.0 & $\mathbf{2 3 . 9}$ & $\mathbf{3 . 5}$ \\
\hline 4. Little chance of advancement. & $\mathbf{1 9 . 0}$ & $\mathbf{2 7 . 5}$ & 35.2 & 14.8 & 3.5 \\
\hline 5. Poor communication with superiors. & $\mathbf{1 4 . 1}$ & $\mathbf{1 7 . 6}$ & 43.0 & 18.3 & 7.0 \\
\hline 6. Insufficient number of employees. & 4.9 & 12.7 & 42.3 & $\mathbf{2 6 . 1}$ & $\mathbf{1 4 . 1}$ \\
\hline 7. Poor work organization. & 4.2 & 26.8 & 35.2 & 23.9 & 9.9 \\
\hline 8. Unforeseen everyday situations. & 6.5 & 12.2 & 52.1 & $\mathbf{2 1 . 1}$ & $\mathbf{8 . 5}$ \\
\hline 9. Administrative affairs. & 6.3 & 12.7 & 37.3 & $\mathbf{2 8 . 2}$ & $\mathbf{1 5 . 5}$ \\
\hline 10. Work overload. & 5.6 & 9.9 & 49.3 & $\mathbf{2 6 . 8}$ & $\mathbf{8 . 5}$ \\
\hline 11. Threat of lawsuit and/or litigation. & 12.0 & 25.4 & 27.5 & 24.6 & 10.6 \\
\hline 12. Inadequate expectations from patients and families. & 4.2 & 23.9 & 41.5 & 21.8 & 8.5 \\
\hline 13. Exposure to inappropriate public criticism. & 6.3 & 21.8 & 37.3 & 23.2 & 11.3 \\
\hline $\begin{array}{l}\text { 14. Misinformation of patients by the media and other } \\
\text { sources. }\end{array}$ & 7.7 & 23.2 & 47.9 & 12.7 & 8.5 \\
\hline 15. Conflicts with patients or their family members. & 7.7 & 22.5 & 39.4 & 23.9 & 6.3 \\
\hline 16. Impossibility of separating professional and private life. & $\mathbf{1 1 . 3}$ & $\mathbf{2 8 . 2}$ & 45.1 & $\mathbf{1 0 . 6}$ & $\mathbf{4 . 9}$ \\
\hline 17. 24-hour responsibility. & 4.2 & 18.3 & 38.0 & $\mathbf{2 7 . 5}$ & $\mathbf{1 2 . 0}$ \\
\hline
\end{tabular}

Table 6. Descriptive data and differences in the perception of stress and the presence of disease by gender

\begin{tabular}{|c|c|c|c|c|c|c|c|}
\hline & & \multicolumn{3}{|c|}{ STRESS } & \multicolumn{3}{|c|}{ DISEASE } \\
\hline & $\mathbf{N}$ & $M$ & SD & t-test & yes & no & $x^{2}$ \\
\hline Male & 41 & 2.86 & 0.556 & \multirow{3}{*}{$\begin{array}{c}-2.126 \\
d f=1 \\
p=0.049^{\star}\end{array}$} & 13 & 28 & \multirow{3}{*}{$\begin{array}{c}1.496 \\
d f=1 \\
p=0.221\end{array}$} \\
\hline Female & 101 & 3.12 & 0.688 & & 45 & 56 & \\
\hline All & 142 & 3.04 & 0.662 & & 58 & 84 & \\
\hline
\end{tabular}


Table 7. Descriptive data and differences in experience of stress and disease presence by age

\begin{tabular}{|c|c|c|c|c|c|c|c|}
\hline & & \multicolumn{3}{|c|}{ STRESS } & \multicolumn{3}{|c|}{ DISEASE } \\
\hline Age group & $\mathbf{N}$ & M & SD & Significance & Yes & No & $x^{2}$ \\
\hline $20-25$ & 23 & 3.10 & .573 & \multirow{10}{*}{$F=0.762$} & 4 & 19 & \multirow{10}{*}{21.344} \\
\hline $25-30$ & 12 & 3.22 & .571 & & 1 & 11 & \\
\hline $30-35$ & 32 & 2.99 & .681 & & 14 & 18 & \\
\hline $35-40$ & 10 & 2.93 & .848 & & 3 & 7 & \\
\hline $40-45$ & 13 & 3.31 & .754 & & 4 & 9 & \\
\hline $45-50$ & 12 & 3.17 & .656 & & 7 & 5 & \\
\hline $50-55$ & 16 & 2.89 & .688 & & 9 & 7 & \\
\hline $55-60$ & 21 & 2.88 & .566 & & 14 & 7 & \\
\hline $60-65$ & 3 & 2.94 & 1.070 & & 2 & 1 & \\
\hline TOTAL & 142 & 3.04 & .662 & & 58 & 84 & \\
\hline
\end{tabular}

${ }^{*} p<0.05$

so a great source of stress. All of these sources lead to feelings of work overload. The respondents consider the following factors as less prominent causes of stress: little chance of advancement, poor communication with superiors, and the impossibility of separating professional and private life.

Table 3 shows that the overall average score of the Workplace Stress questionnaire is 3.04, which corresponds to an estimate of 'sometimes stressful'. Men rate stress slightly less (2.86) than women (3.12). Testing the significance of the difference in average scores of the stress questionnaire indicates a marginal but still statistically significant difference. A statistically significant difference was obtained in the average overall score of experienced stress in men and women.

The chi-square test tested the significance of the difference in the incidence of the disease in men and women. The result indicates that there is no statistically significant difference in the presence of the disease in men and women.

Table 7 shows the average total values of experienced stress by age groups. Analysis of variance tested whether respondents of different ages differed in experienced stress. No statistically significant difference was obtained, so we conclude that there are no differences in the estimated experienced stress in relation to age. In other words, respondents, regardless of their age, equally experience stress at work.

The chi-square test was used to check whether there were differences in the presence of the disease in relation to the age of the subjects. As expected, a statistically significant difference in the presence of the disease was obtained in subjects of different ages. The association between age and disease was statistically significant $(r=0.339 ; p=0.0)$ and positive. As one grows older, the probability or presence of disease increases. One worrying fact is that there is the same number of sick respondents between the ages of 30 and 35 as in the group of respondents aged between 55 and 60 .

Table 8 shows the average total values of experienced stress according to the number of years of work experience. The analysis of variance shows that there is no statistically significant difference in the experienced stress in relation to the years of work experience of the respondents, i.e., regardless of the number of years of work experience, the respondents experience the same stress. A statistically significant difference was obtained in the presence of the disease in relation to the number of years of work experience. The association between work experience and disease presence was also statistically significant ( $r=0.261 ; p=0.002)$. 
Table 8. Descriptive data and differences in the experience of stress and the presence of disease according to work experience

STRESS

\begin{tabular}{|c|c|c|c|c|c|c|c|}
\hline $\begin{array}{l}\text { Years of work } \\
\text { experience }\end{array}$ & $\mathbf{N}$ & M & SD & Significance & Yes & No & $x^{2}$ \\
\hline $0-10$ & 43 & 3.13 & .620 & \multirow{6}{*}{$\begin{array}{c}F=0.861 \\
d f=4 \\
p=0.489\end{array}$} & 11 & 32 & \multirow{6}{*}{$\begin{array}{c}11.792 \\
\mathrm{df}=4 \\
p=0.019^{*}\end{array}$} \\
\hline $10-20$ & 33 & 3.01 & .633 & & 11 & 22 & \\
\hline $20-30$ & 29 & 3.12 & .769 & & 14 & 15 & \\
\hline $30-40$ & 32 & 2.91 & .624 & & 20 & 12 & \\
\hline $40-$ & 5 & 2.77 & .806 & & 2 & 3 & \\
\hline TOTAL & 142 & 3.04 & .662 & & 58 & 84 & \\
\hline
\end{tabular}

Table 9. Descriptive data and differences in the experience of stress and the presence of disease according to education

\begin{tabular}{|c|c|c|c|c|c|c|c|}
\hline & & \multicolumn{3}{|c|}{ STRESS } & \multicolumn{3}{|c|}{ DISEASE } \\
\hline Age & $\mathbf{N}$ & M & SD & Significance & yes & no & $\chi^{2}$ \\
\hline $\begin{array}{l}\text { High school } \\
\text { graduate }\end{array}$ & 99 & 2.97 & 0.679 & \multirow{4}{*}{$\begin{array}{c}f=1.846 \\
d f=2 \\
p=0.162\end{array}$} & 37 & 62 & \multirow{4}{*}{$\begin{array}{c}2.057 \\
\mathrm{df}=2 \\
p=0.358\end{array}$} \\
\hline $\begin{array}{l}\text { University } \\
\text { graduate } \\
\text { (3 years of } \\
\text { study) }\end{array}$ & 29 & 3.21 & 0.594 & & 14 & 15 & \\
\hline $\begin{array}{l}\text { University } \\
\text { graduate } \\
\text { (more than } \\
3 \text { years of } \\
\text { study) }\end{array}$ & 13 & 3.19 & 0.650 & & 7 & 6 & \\
\hline TOTAL & 141 & 3.04 & 0.664 & & 58 & 83 & \\
\hline
\end{tabular}


Table 9 shows descriptive data on the experience of stress and the presence of disease according to the education of the respondents. Analyses show that there is no statistically significant difference in the assessment of stress and the presence of the disease among subjects based on different levels of education.

The difference in the experience of stress of respondents who are currently suffering from a disease and those who are not was examined. No statistically significant difference was obtained between these two groups ( $\mathrm{t}=-, 642, \mathrm{df}=140, p=0.522)$. In other words, both those who are ill and those who are not ill experience an equal degree of stress.

\section{Discussion}

By analysing the Health Questionnaire, we have discovered that $40.8 \%$ of respondents suffer from some disease. On the positive side, only $16.9 \%$ of them have been treated in hospital for the past two years, while $67.6 \%$ of them have been treated by family doctors. Two-thirds of respondents take a medication occasionally or continuously. 31\% of respondents were tested for infectious diseases. $45.8 \%$ of respondents were never pregnant, while the rest were pregnant one or more times. $72.5 \%$ of respondents stated that they did not have any problems in pregnancy.

Allergic difficulties are closely related to excessive psychological stress. Allergic diseases are the most common cause of disorders of the immune system or cytokine imbalance (10). According to the results of this study, allergic difficulties predominate in all age groups, mostly in younger age groups and in women, which speaks in favour of similar results obtained in other studies (10). Allergic diseases are also considered adaptation diseases (6). Asthma is also associated with stress due to inflammatory processes caused by stress. As with other diseases, oxidative stress plays an important role in the development of the disease (11). Almost $50 \%$ of children with atopic dermatitis develop asthma while as many as $75 \%$ develop allergic reactions (10). This study showed the highest number of asthma sufferers among those aged between 20 and 35. Asthma is a disease that has been confirmed to be more prevalent in younger age. According to the results of this study, thyroid diseases are present among those aged between 20 and 60 . According to some studies, stress is frequently associated with the onset of Graves' disease (12). Thyroid disease is predominantly much more common in women.

Allostatic condition increases the risk of autoimmune diseases $(7,8,10)$. The most common stress-related diseases are lupus and rheumatoid arthritis (8). This study showed a higher number of autoimmune diseases among those aged 45 and above, which would correspond to the fact that a longer period of exposure to stress leads to the development of the disease. The study by Song et al. showed that younger persons had a higher risk of developing autoimmune diseases, while PTSD is considered to be a major disorder associated with the development of autoimmune diseases (13). As many as $50 \%$ of autoimmune diseases do not have a clear disease trigger (14).

Stress leads to increased sensitivity of the mucosa in the small intestine, where gram-negative bacteria easily penetrate and cause inflammatory changes (15). A study by Jansson et al. showed that people with low job satisfaction have twice the risk of developing GERD, as do those prone to self-pressure or time pressure (16). Stressful life situations can increase the risk of developing inflammatory bowel disease, GERD, and peptic ulcer (17). In this study, subjects reported gastrointestinal diseases, most commonly reflux and to a lesser extent, ulcers.

Nurses' exposure to stress makes them a group that is at high risk of developing depression (18). This study has a small number of responses in which respondents cite mental difficulties or illnesses which may be a certain indicator for denying the existence of mental problems.

Oxidative stress is one of the important causes of many diseases. It is also involved in the pathophysiology of diabetes and cardiovascular disease (19). When carbohydrates are ingested and broken down, free radicals are released. Excessive amounts of free radicals lead to oxidative stress. A study by Wang et al. showed an increased risk of developing metabolic syndrome symptoms (obesity, hypertension, increased triglycerides) in nurses working night shifts (3). Allostatic load of type 2 leads to increased concentrations of glucocorticoids, which cause increased appetite and consequently increased food consump- 
tion. Excess energy obtained from food is deposited as fat or results in obesity (8). Obesity also affects the development of autoimmune diseases (14).

Hypertension is a common disease in the elderly (20). It is the result of the influence of genetic and environmental conditions (21). Oxidative stress also plays a role in the development of hypertension. Some studies have shown that oxidative stress has a greater effect on blood pressure in men (22). Psychosocial stress leads to an increased risk of developing hypertension (23). The expected results of patients with hypertension were obtained in those subjects who have over 30 years of work experience or who are between 45 and 60 years of age.

Oxidative stress increases the risk of skin diseases and aging. Inflammatory factors that occur in the middle of the oxidative process have a strong influence on the development of skin cancer (24). Some autoimmune skin diseases such as psoriasis, vitiligo, and alopecia may be associated with oxidative stress or imbalance of oxidative and antioxidant processes (25). Elevated levels of daily stress can affect lower cortisol levels, which can result in a detrimental effect on skin disease and its treatment (26). This research showed that in a large number of subjects skin changes occurred between the ages of 45 and 60 after 30 to 40 years of work experience. Therefore, it is impossible to clearly determine whether stress influenced the onset of the disease, which is supported by the perception of equal experience of stress by sick and healthy subjects.

The results of the questionnaire on stress in the workplace of hospital health workers show that the respondents cited small possibility of advancement, poor communication with superiors, and the inability to separate work and private life as not significantly stressful factors. It has been shown that a "healthy" work environment and mutual support of colleagues in the workplace lead to better efficiency at work and reduced stress levels, which in turn leads to better care (27). Nurses in hospitals showed higher levels of stress than those outside hospitals (28). It has been shown that poor atmosphere in the workplace and the pressure of work result in higher dissatisfaction of the staff, which matches the results of other studies. Hospitals should have organized training on stress management, regular meetings with colleagues and superiors, optimal shift work, and improved occupational health safety conditions to keep nurses' stress at an acceptable level (29). Some studies have shown that nurses are stressed by the ag- gressive behaviour of other nurses, physicians, and colleagues, while some have been stressed by verbal aggression of patients (30). Psychiatric patients have proven to be more difficult, demanding, and dangerous, causing stress for those who work with them (31). The respondents cited the following factors as causes of stress: inadequate personal income, inadequate material resources for work, inadequate workspace, insufficient number of workers, unforeseen daily situations, administrative work, work overload, and 24-hour responsibility. Occupational stress may be associated with personal and workplace problems (31). A study conducted in Wales found that $51 \%$ of nurses experience high levels of long-term emotional exhaustion related to stress and workplace conditions. Factors such as increased work responsibilities and lack of support from colleagues can also be stressful (32).

According to the results of this study, respondents are moderately stressed by poor work organization, the threat of lawsuits, inadequate expectations from families and patients, exposure to public criticism, misinformation of patients and families by the media and other sources, and conflicts with patients and their family members. A study by Kane shows that moderate stressors are present in most nurses (5). Dissatisfaction with pay can affect the level and quality of care provision $(33,34)$. Corruption can also affect service delivery (34). Long-term stress can affect nursing decisions, as well as the ability to meet the patient's needs, which in turn leads to exhaustion and sick leave (35). The way nursing and nursing work is organized can predict the motivation and satisfaction of nurses. It has not been clearly demonstrated that organizational models influence stress in nurses (36).

\section{Conclusion}

This study found an association between age and work experience with the likelihood of illness, although both the healthy and the sick perceive equal levels of stress. The most common diseases among the subjects are cardiovascular diseases, thyroid diseases, gastrointestinal diseases and allergic diseas- 
es. One disadvantage of this study is that it covers a large field and deals with general matters, but it can certainly be a starting point for further, more precise research.

It would be interesting to repeat this study in 10 to 15 years. Given that a large number of respondents could participate in the survey again, such a study would show whether the results remained the same, or whether they improved or worsened. In the Republic of Croatia, a small number of studies have been conducted on this topic, which is why the conclusions of this study cannot be generalized.

\section{References}

1. Sharma P, Davey A, Davey S, Shukla A, Shrivastava K, Bansal R. Occupational stress among staff nurses: Controlling the risk to health. Indian J Occup Environ Med. 2014;18(2):52-6.

2. Ramin C, Devore EE, Wang W, Pierre-Paul J, Wegrzyn LR, Schernhammer ES. Night shift work at specific age ranges and chronic disease risk factors. Occup Environ Med. 2015;72(2):100-7.

3. Wang XS, Armstrong MEG, Cairns BJ, Key T], Travis RC. Shift work and chronic disease: The epidemiological evidence. Occup Med (Chic III). 2011;61(2):78-89.

4. Marquezea EC, Lemosa LC, Soaresa N, Lorenzi-Filhob $\mathrm{G}$, Morenoa CRC. Weight gain in relation to night work among nurses. Work. 2012;41(Suppl.1):2043-8.

5. Kane PP. Stress causing psychosomatic illness among nurses. Indian J Occup Environ Med. 2009;13(1):2832.

6. Debogović S. Stres na radnom mjestu i njegovi učinci na zdravlje medicinskih sestara i tehničara [završni rad]. Sveučilište Sjever; 2015. Croatian.

7. Klein R. Stress physiology and pathology. Available from: https://web.archive.org/ web/20061017061323/http://www.rrreading.com/ files/Thesis 3.pdf

8. McEwen BS, Wingfield JC. The concept of allostasis in biology and biomedicine. Horm Behav. 2003;43(1):215.

9. Logan JG, Barksdale DJ. Allostasis and allostatic load: Expanding the discourse on stress and cardiovascular disease. J Clin Nurs. 2008;17(7B):201-8.

10. Dave ND, Xiang L, Rehm KE, Marshall GD. Stress and Allergic Diseases. Immunol Allergy Clin North Am. 2011;31(1):55-68.
11. Galli F, Ronco C. Oxidant stress in hemodialysis. Nephron. 2000;84(1):1-5.

12. Falgarone G, Heshmati HM, Cohen R, Reach G. Role of emotional stress in the pathophysiology of Graves' disease. Eur J Endocrinol. 2013;168(1):12-8.

13. Song $\mathrm{H}$, Fang F, Tomasson G, Arnberg FK, Mataix-Cols D, De La Cruz LF, et al. Association of stress-related disorders with subsequent autoimmune disease. JAMA - J Am Med Assoc. 2018;319(23):2388-400.

14. Stojanovich L, Marisavljevich D. Stress as a trigger of autoimmune disease. Autoimmun Rev. 2008;7(3):20913.

15. Lambert GP. Stress-induced gastrointestinal barrier dysfunction and its inflammatory effects. J Anim Sci. 2009;87(14 Suppl):101-8.

16. Jansson C, Wallander MA, Johansson $S$, Johnsen $R$, Hveem K. Stressful psychosocial factors and symptoms of gastroesophageal reflux disease: A population-based study in Norway. Scand J Gastroenterol. 2010;45(1):21-9.

17. Mayer EA. The neurobiology of stress and gastrointestinal disease. Gut. 2000;47(6):861-9.

18. Wang SM, Lai CY, Chang YY, Huang CY, Zauszniewski JA, Yu CY. The relationships among work stress, resourcefulness, and depression level in psychiatric nurses. Arch Psychiatr Nurs. 2015;29(1):64-70.

19. Skalicky J, Muzakova V, Kandar R, Meloun M, Rousar T, Palicka V. Evaluation of oxidative stress and inflammation in obese adults with metabolic syndrome. Clin Chem Lab Med. 2008;46(4):499-505.

20. Higashi Y, Kihara Y, Noma K. Endothelial dysfunction and hypertension in aging. Hypertens Res. 2012;35(11):1039-47.

21. Sun Z. Aging, arterial stiffness, and hypertension. Hypertension. 2015;65(2):252-6.

22. Lopez-Ruiz A, Sartori-Valinotti J, Yanes LL, Iliescu $R$, Reckelhoff JF. Sex differences in control of blood pressure: Role of oxidative stress in hypertension in females. Am J Physiol - Hear Circ Physiol. 2008;295(2):466-74.

23. Liu MY, Li N, Li WA, Khan H. Association between psychosocial stress and hypertension: a systematic review and meta-analysis. Neurol Res. 2017;39(6):57380.

24. Kruk J, Duchnik E. Oxidative stress and skin diseases: Possible role of physical activity. Asian Pacific J Cancer Prev. 2014;15(2):561-8.

25. Shah $A A$, Sinha $A A$. Oxidative stress and autoimmune skin disease. Eur J Dermatology. 2013;23(1):5-13.

26. Evers AWM, Verhoeven EWM, Kraaimaat FW, De Jong EMGJ, De Brouwer SJM, Schalkwijk J, et al. How stress gets under the skin: Cortisol and stress reactivity in psoriasis. Br J Dermatol. 2010;163(5):986-91.

27. Abu Al Rub RF. Job stress, job performance, and social support among hospital nurses. J Nurs Scholarsh. 2004;36(1):73-8. 
28. Rusac S, Bošnjak M, Kletečki Radović M. Profesionalni stres medicinskih sestara u domovima za starije osobe. Sigurnost. 2017;59(1):7-18. Croatian.

29. Golubic R, Milosevic M, Knezevic B, Mustajbegovic J. Work-related stress, education and work ability among hospital nurses. J Adv Nurs. 2009;65(10):2056-66.

30. Kowalczuk K, Klimaszewska K, Rolka H. Influence of aggression on stress development in the population of nurses and midwives in the Podlaskie Province. 2010;91(3):444-50.

31. Hamaideh SH. Occupational stress, social support, and quality of life among Jordanian mental health nurses. Issues Ment Health Nurs. 2012;33(1):15-23.

32. Edwards D, Burnard P, Coyle D, Fothergill A, Hannigan $B$. Stressors, moderators and stress outcomes: Findings from the All-Wales Community Mental Health Nurse Study. J Psychiatr Ment Health Nurs. 2000;7(6):529-37.
33. Robyn PJ, Bärnighausen $T$, Souares $A$, Traoré $A$, Bicaba $B$, Sié $A$, et al. Provider payment methods and health worker motivation in community-based health insurance: A mixed-methods study. Soc Sci Med. 2014;108:223-36.

34. Mæstad 0, Mwisongo A. Informal payments and the quality of health care: Mechanisms revealed by Tanzanian health workers. Health Policy (New York). 2011;99(2):107-15.

35. Billeter-Koponen S, Fredén L. Long-term stress, burnout and patient-nurse relations: Qualitative interview study about nurses' experiences. Scand J Caring Sci. 2005;19(1):20-7.

36. Mäkinen A, Kivimäki M, Elovainio M, Virtanen M. Organization of nursing care and stressful work characteristics. J Adv Nurs. 2003;43(2):197-205. 


\section{Sažetak}

Homeostaza u našem organizmu pokušava održavati stabilnost koja je važna za normalno funkcioniranje organizma. Alostatski mehanizmi dodatno pomažu u uspostavljanju te ravnoteže. Kronični stres izaziva složeno stanje u organizmu koje se naziva alostatsko opterećenje. Ako takvo opterećenje potraje, znatno se povećava rizik od nastanka neke bolesti. Ovo istraživanje provedeno je anonimno u cilju utvrđivanja zdravstvenog stanja medicinskih tehničara i medicinskih sestara u Neuropsihijatrijskoj bolnici „Dr. Ivan Barbot" u Popovači i njihova izloženost svakodnevnim stresorima na radnom mjestu. Glavna svrha bila je ispitati vezu između stresa i zdravstvenog stanja medicinskih sestara u odnosu na spol, dob i staž. Sudjelovale su ukupno 142 medicinske sestre. Primijenjeni su zdravstveni upitnik i upitnik za stres na radnom mjestu. Rezultati su pokazali da su najčešće bolesti od kojih boluju medicinske sestre kardiovaskularne bolesti, bolesti štitnjače, gastrointestinalne bolesti i alergije. Žene su pokazale veću osjetljivost na stres od muškaraca. Najčešći stresori s kojima se medicinske sestre susreću na radnom mjestu jesu neadekvatna osobna primanja, neadekvatni radni prostor i materijalna sredstva za rad, nedostatak broja djelatnika, svakodnevne nepredviđene situacije, 24-satna odgovornost i administrativni poslovi. Najčešće bolesti ispitanika jesu kardiovaskularne bolesti, bolesti štitnjače, gastrointestinalne bolesti i alergijske bolesti. Ovo istraživanje utvrdilo je povezanost dobi, posljedično i radnog staža s vjerojatnošću oboljenja, iako i zdravi i bolesni percipiraju podjednaku razinu stresa. Manjkavost je ovog istraživanja što obuhvaća veliko područje i bavi se općenitim stvarima, ali svakako može biti polazište za daljnja preciznija istraživanja. I dalje ostaje mnogo otvorenih pitanja, što otvara potrebu za daljnjim istraživanjima i proučavanjem poveznice između stresa i bolesti.
Ključne riječi: alostaza, alostatsko opterećenje, bolest, homeostaza, medicinske sestre, stres 